\title{
Actually existing smart citizens: expertise and (non)participation in the making of the smart city
}

\author{
Forthcoming in City
}

\author{
Taylor Shelton ${ }^{\mathrm{a}}$ \\ taylor.shelton@msstate.edu \\ Thomas Lodato ${ }^{\mathrm{b}}$ \\ thomas.lodato@gmail.com
}

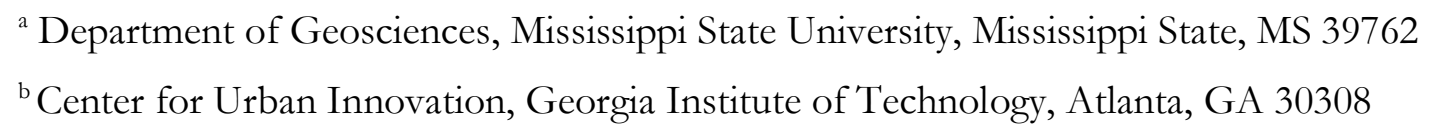

ABSTRACT:

In response to the mounting criticism of emerging 'smart cities' strategies around the world, a number of individuals and institutions have attempted to pivot from discussions of smart cities towards a focus on 'smart citizens'. While the smart citizen is most often seen as a kind of foil for those more stereotypically top-down, neoliberal, and repressive visions of the smart city that have been widely critiqued within the literature, this paper argues for an attention to the 'actually existing smart citizen', which plays a much messier and more ambivalent role in practice. This paper proposes the dual figures of 'the general citizen' and 'the absent citizen' as a heuristic for thinking about how the lines of inclusion and exclusion are drawn for citizens, both discursively and materially, in the actual making of the smart city. These figures are meant to highlight how the universal and unspecified figure of 'the citizen' is discursively deployed to justify smart city policies, while at the same time, actual citizens remain largely excluded from such decision and policy-making processes. Using a case study of Atlanta, Georgia and its ongoing smart cities initiatives, we argue that while the participation of citizens is crucial to any truly democratic mode of urban governance, the emerging discourse around the promise of smart citizenship fails to capture the realities of how citizens are actually discussed and enrolled in the making of these policies. 


\section{The Emergence of the Smart Citizen}

At this juncture, pointing out the disconnect between the promise of the 'smart city' and its actual implementation is rather uncontroversial. Dominated by visions of technology-enabled urban revitalization, economic development, community engagement, and improved citizen well-being, smart city efforts have instead operated as a way for private and corporate interests to further interject themselves into urban governance and development processes in a top-down manner. Although they masquerade as a public good, smart city efforts are largely indistinguishable from earlier iterations of neoliberal urbanism. So rather than providing a cure-all to lagging cities, the smart city instead reinscribes already substantial urban social and spatial inequalities by privileging free market, technology-centric, and expert-driven forms of urban planning and governance, forcing cities to compete for scarce resources in new ways.

While these issues have become increasingly well-documented in the nascent critical literature on the smart city, many such critiques are addressed more towards the increasingly voluminous marketing literature put out by smart city vendors or the yet-to-be-built 'greenfield' smart cities of the global south (cf. Greenfield 2013; Soderstrom et al 2014; Sadowski and Pasquale 2015; White 2016), and less towards the material conditions and changes underway in 'actually existing smart cities' in North America and western Europe (Shelton et al 2015). Regardless of the continued need for more detailed and nuanced empirical accounts of smart city projects as they're actually being implemented (cf. Kitchin 2015), it's widely evident that the smart city isn't all it's cracked up to be. Even acknowledging that this isn't a movement driven solely by profit-maximizing technology companies like IBM, AT\&T, and Google, the kind of pervasive 'technological solutionism' inherent in all iterations of the idea remains a cause for concern. At the very least, even the most benign of smart city efforts are incredibly resource intensive in terms of both financial and human resources, pulling attention away from less spectacular, though still substantive and pressing, problems facing cities.

In response to the mounting criticism along these lines, a number of individuals and entities have attempted to pivot this ongoing discussion of 'smartness' from one of 'smart cities' to that of 'smart citizens', a shift crystallized in Dan Hill's (2013) blogpost-qua-manifesto entitled "On the smart city; Or, a 'manifesto' for smart citizens instead". Hill's commentary is particularly important in its stark dichotomy between the vision of the smart city on the one hand, and that of the smart citizen on the other; a recognition that the former is, in effect, too far gone to save, and that only by shifting both our discourse and interventions to be more citizen-centric can we actually achieve any meaningful change. But Hill has not been alone in this call for smart citizens, nor in the clear contrasts between this vision and the more conventional imaginary of smart cities. The last couple of years have seen countless articles and editorials float around the internet making similar claims, with headlines like "While governments talk about smart cities, it's citizens who create them", "Only Smart Citizens can enable true Smart Cities", "Smart city needs smart citizens too", "Without smart citizens, smart cities don't stand a chance", and "Are smart citizens getting lost in the rush to build smart cities?" (Upadhyaya 2015; Allessie 2016; Power 2016; Ratti 2016; Shein 2016). But increasingly, the 'smart citizen' discourse isn't mobilized solely in opposition to more conventional smart city imaginaries. Indeed, as Kitchin (2015) has noted, even "smart city vendors such as IBM and Cisco have started to alter the discursive emphasis of some of their initiatives from being top-down managerially focused to stressing inclusivity and empowerment" (133). 
This paper argues that while the 'smart citizen' is most often seen as a kind of foil for those more stereotypically top-down, neoliberal, and repressive visions of the smart city, the 'actually existing smart citizen' plays a much messier and more ambivalent role in practice - both as this figure gets deployed discursively in the everyday practices of smart city-making, as well as in the actually existing practices of citizens participating (or not participating) in such efforts. In particular, we propose the dual figures of 'the general citizen' and 'the absent citizen' as a heuristic to understand the dominant ways that citizens are actually framed, enrolled and mobilized to particular ends by powerful actors and institutions guiding smart city planning initiatives. Through these two figures we first highlight the ways the more general, universal, unspecified and undifferentiated figure of 'the citizen' is discursively deployed in order to justify smart city policy-making, but in a way that fails to grapple with the very real contours of social and spatial inequality in the contemporary city. Second, we show that in spite of the discursive centrality of the general citizen to the way these initiatives are thought about and enacted, actual citizens remain largely excluded from participating in such decision and policy-making processes around smart city strategies. That is, we see these two figures as providing an outline of how the citizen is constituted in the actually existing smart city, or, as Secor (2003) suggests with regard to citizenship more broadly, how lines of inclusion and exclusion are drawn both discursively and materially. While other heuristic frameworks for understanding smart citizenship have been proposed by the likes of Vanolo (2016), Joss et al (2017), Cardullo and Kitchin (Forthcoming), de Waal and Dignum (2017) and Cowley at al (forthcoming) - many of which resonate with our own framing, especially in terms of issues of non-participation and civic paternalism - we believe that our two ideal-type figures provide a more concise summary of how citizens are actually positioned within smart city planning efforts on-the-ground, rather than solely in government or corporate planning and marketing documents.

While the overarching discourses of smart citizenship are, like the broader discourses around the smart city, ripe for critique, it's important that these discourses be grounded in the particular contexts in which they're mobilized, which affect both their production and their outcomes. As such, in this paper we draw from our own participant observation of multiple, ongoing smart city planning efforts in Atlanta, Georgia, a city that has been keen to position itself at the forefront of smart city visioning in North America. While the empirical material here is drawn particularly from the authors' attendance at a closed-door planning meeting and public panel discussion around the city's smart city planning efforts, our interpretations of these events is informed by more extensive research on and within the city's smart city efforts. While the particularities of Atlanta may not be universally applicable to each and every city, we believe the context of a highly unequal and segregated city pursuing smart city efforts to be particularly instructive for further study and critique of 'actually existing smart cities'. And while this place-based, empirical grounding represents an important aspect of capturing the smart city and smart citizen as they 'actually exist', so too does our argument attempt to demonstrate the always messy and contradictory ways that these ideas are implemented in practice, and how they intersect with, are shaped by, and help to reproduce other social and spatial processes, even if these don't necessarily mirror the clean breaks or direct continuities posited by some accounts.

The rest of the paper proceeds as follows: first, the paper turns to reviewing in more detail the ways that the smart citizen has been discussed by those both optimistic and critical of this discourse and its potential to reshape the broader discourse and practice surrounding the smart city. Second, the paper explores the figure of the 'actually existing smart citizen' through the dual figures of the 'general' and 'absent' citizen, and how the emerging popular discourse around the smart citizen fails to capture the ways that citizens are discursively and materially figured in the making of these 
policies. The paper concludes by considering what the various inclusions and exclusions of 'actually existing smart citizens' mean for the discourse around 'smart citizens' and for our broader conceptualizations of urban citizenship. We ultimately see drawing attention to these 'actually existing' formulations as offering the potential for moving beyond such a limited conception of smart citizenship within contemporary urban planning and governance, suggesting the need for more genuinely democratic and egalitarian participation processes within smart city efforts.

\section{Situating the Smart Citizen}

Although smart city programs and initiatives continue to grow in the United States and across the world (cf. The White House 2015; President's Council of Advisors on Science and Technology 2016), the idea of the smart city, and of a technology-centric vision of urban life and urban governance more generally, have become the subject of significant critique in recent years. This critique is perhaps best seen in Adam Greenfield's (2013) polemical Against the Smart City, which calls to task the variety of multinational technology companies building new 'cities from scratch' around the globe. A variety of critical social scientists and practitioners alike have further pinpointed a number of key issues with the prevailing discourses around and plans for smart city developments. Most notably, the smart city idea has been attacked for representing an overt intensification of neoliberal urbanism; a devolution of urban governance to multinational technology corporations, who are interested primarily in maximizing their profits by capturing a new urban market for onesize-fits-all policies and technologies, rather than actually making substantive improvements to the quality-of-life for urban residents around the world (cf. Hollands 2008, 2015; Soderstrom et al 2014; Viitanen and Kingston 2014; McNeill 2015; Wiig 2015). This trend is so significant that even some of the most ostensibly community-oriented approaches to urban technology, such as the open data movement, are seen to have largely been co-opted and fit into the broader ethos of a 'smart' entrepreneurialism (Barns 2016). Beyond this broad critique of the corporatization of urban governance under the smart city, Kitchin (2014) has outlined a number of other overarching issues, such as the potential for pervasive surveillance and the creeping technocracy associated with the centering of 'big data' in urban decision-making processes.

Though many of these critiques have been leveled at the general idea of the smart city represented in the celebratory marketing literature offered up by its boosters, or its manifestation in 'greenfield' sites like Songdo, South Korea (Halpern et al 2013) or Dholera, India (Datta 2015), rather than any number of projects being implemented in already-existing urban contexts, these critiques have been relatively successful in providing a counterweight to the conventional smart city imaginary. But as this critique has taken hold, so too have those being critiqued attempted to rework their discursive framing, so as to address these criticisms without fundamentally changing the underlying nature of their projects. One of the key aspects of the conventional smart city imaginary under scrutiny has been its lack of people, an issue highlighted recently by Vanolo (2016) in his examination of the multiple ways that citizens have been treated within different smart city visions. From the CITE urban test-bed in southern New Mexico (Monks 2015) to the largely constructed but un-populated Masdar City development in Abu Dhabi (Eymeri 2014), some of the most prominent examples of smart cities, even when brought to fruition, are absent of actual living and breathing human beings.

It is against this backdrop of a top-down, neoliberal, technocratic and people-less vision of the smart city - and an increasingly prominent critique thereof - that Dan Hill's (2013) "manifesto for the smart citizen" emerged as a meaningful alternative discourse. Still optimistic about the potentials of 
technology, just not under the conditions seemingly being set by the large technology companies, he argued that:

\begin{abstract}
"Instead of the smart city, perhaps we should be more preoccupied with smart citizens. The smart city vision tends to focus on infrastructure, buildings, vehicles, looking for a client amidst the city governments that procure or plan such things. But the city is something else. The city is its people. We don't make cities in order to make buildings and infrastructure. We make cities in order to come together, to create wealth, culture, more people" (Hill 2013).
\end{abstract}

Similar arguments being made concurrently by Anthony Townsend (2013) and Saskia Sassen (2012) again point towards a series of alternative technologies and social organizations that run counter to the top-down, command-and-control-style smart city: civic hacking, crowdfunding, ride-sharing, neighborhood social networking platforms and the reporting of issues to municipal government via 311 apps. While still very much enabled by, if not focused on, technology, these examples are thought to represent a more bottom-up, context-sensitive, and citizen-centric vision of the smart city, responding to actual problems being experienced by people in cities today, in a way that can be more widely accessed than some of the expert-driven systems often associated with smart cities. For Sassen, the technological potential of smart cities needs to be opened up to citizens through a kind of 'open source urbanism' or 'urban WikiLeaks', "the need [is] to design a system that puts all that technology truly at the service of the inhabitants, and not the other way around" (Sassen 2012). Most often in this emerging 'smart citizen' discourse, the means by which we can realize Sassen's vision "[are] here, literally in the hands of citizens, via phones and social media" (Hill 2013). Townsend (2014) even likens the smartphone to Patrick Geddes' famed Outlook Tower in Edinburgh, which helped to inaugurate the modern approach to urban planning, as the technical means by which we can come to know the city and act in/on it as 'smart citizens'. Of course, such a smartphone-centric vision of citizen engagement in the smart city has also been taken up by some of the more top-down visions of smart cities being implemented, such as in New York City's 'quantified community' of Hudson Yards (Mattern 2016).

The fact that many of these initiatives are already developed in a number of cities, if at times underrecognized and under-utilized, is seen as promising for the future of the smart city idea. Citizens are indeed already organizing themselves using new technologies in order to make their cities better places to live, to varying results (cf. Gordon and Manosevitch 2011; Wilson 2011; Ehn et al 2015; Offenhuber 2015; Hoyng 2016; Le Dantec et al 2016; Lodato and DiSalvo 2016; Zandbergen 2017; Perng and Kitchin 2018; Tironi and Valderrama, forthcoming). That being said, there remain significant differences in how these emerging discourses and practices of 'smart citizenship' ought to be interpreted. Most notably, Jennifer Gabrys (2014) posits a significantly less optimistic view of what these processes mean for citizenship in the smart city. For her, the transformation of citizens into sensors also means that "citizenship transforms into citizen sensing", that "[m]onitoring and managing data in order to feed back information into urban systems are practices that become constitutive of citizenship" (34). Rather than representing a democratization of data or a more active role for citizens in the construction of the urban, Gabrys sees this kind of reconfiguration of citizenship as fundamentally more passive. In this formulation:

"The actions of citizens have less to do with individuals exercising rights and responsibilities, and more to do with operationalizing the cybernetic functions of the smart city. Participation involves computational responsiveness and is coextensive 
with actions of monitoring and managing one's relations to environments, rather than advancing democratic engagement through dialogue and debate. The citizen is a data point, both a generator of data and a responsive node in a system of feedback" (Gabrys 2014: 38)

She continues to argue that "[i]t may be that the very responsiveness that enables citizens to gather data does not extend to enabling them to meaningfully act upon the data gathered, since this would require changing the urban 'system' in which they have become effective operators" (43). That is, the role of the citizen-as-sensor - again, a key, pervasive element of even the most optimistic visions of the 'smart citizen', enabled largely by the smartphones we all carry around in our pockets - is one where citizens have extremely circumscribed roles, which exclude them from a fundamental questioning, or ultimately changing, of such roles or the processes of urban governance. Or, as Shannon Mattern puts it:

"We're empowered to report failed trash pick-ups or rank our favorite hospitals, but not entitled to know what happens to our personal data each time we pass through a toll booth, or how the doctor we rarely see knows our cholesterol is up. We often have little understanding of how and where the mediation of urban system takes place within the city itself. Nor do we know how our intelligence translates into urban 'sentience', and what is gained or lost in the conversion" (Mattern 2014, emphasis in the original)

This view of smart citizenship as fundamentally passive dovetails with the different frameworks offered more recently by the likes of Cardullo and Kitchin (Forthcoming) and Cowley et al (forthcoming). In their reappraisal of Arnstein's (1969) 'ladder of citizen participation', Cardullo and Kitchin offer a 'scaffold of smart citizen participation', primarily by adding a rung for the increasingly dominant 'citizen-as-consumer'. Similarly, Cowley et al (forthcoming) offer a schematic for understanding the ways that smart cities enroll different visions of the public, or citizens, into their making. As they demonstrate, the dominant ways in which citizens are conceptualized, at least through smart city initiatives across six cities in the UK, are through what they call the 'service-user' and 'entrepreneurial' modalities. Each of these frameworks reinforces a view of citizens as simply the recipients of smart city initiatives, rather than fundamental co-creators of these policies and programs. At best, they seem to enroll citizens as part of a broader entrepreneurial ethos, rather than out of a sense of civic duty or the public good.

So while the popular discourse of the smart citizen attempts to present a break with the almost selfevidently neoliberal vision of the smart city, these nascent critiques point to the fact that it actually represents a significant continuity with neoliberal understandings of citizenship. This divergence between popular discourse and critique is, as Kelty (2017) explains, fundamental to the cultural meaning of participation, and vital to understanding what motivates participatory efforts that rely on the concept of the smart citizen. Oscillating between an "optative" mood - "a happy hypothesis of change through the involvement of more people rather than fewer" - and a "critical" mood - "what is called participation becomes a false claimant: phony participation." (Kelty 2017: S87) participation is not just an activity, but a cultural product. The presence of this underlying neoliberal model of the citizen helps us to grapple with the seeming tension between the smart citizen as an active contributor to the cybernetic system of the smart city and as a passive consumer of its services, a tension that requires attention to the sites and performances of these differences. For at the same time as the smart city responsibilizes citizens by placing the onus for the city's success on 
their shoulders (cf. Vanolo 2014), it simultaneously disempowers them, reducing these citizens, and the notion of citizenship more broadly, to mere data points and the contribution thereof, or to cogs in the machine of capital accumulation. That is, what Cowley et al understand as the 'civic' or 'political' modalities of the publicness are superseded by the market, and by the valorization of citizens as an instrumental means to such an end.

That is to say, much of the nascent critical scholarship on smart citizens has already identified the tension between the hopeful aspirations of enrolling citizens in the creation of the smart city and the actual practices of investing citizens with significant power to shape the making of such a city. Being a citizen in a smart city does not necessarily make one a 'smart citizen' - indeed, there's something of substantive disconnect between these two ideas. And yet, the notion of the 'smart citizen' continues to be invoked as a kind of alternative or foil to the more dominant, conventional understandings of the smart city. While we want to make clear that not all variations on the smart city or smart citizen discourse are made equal, we remain highly skeptical that simply invoking a vision of smart citizens in contrast to one of smart cities represents a sufficient shift in our collective approach to these issues. Indeed, as we hope to demonstrate in the following section, we have reservations about the ability of citizens to be integrated into smart city efforts in any meaningful way, given the kind of persistent ambiguity surrounding how citizens are thought of in the context of the already neoliberal and exclusionary context of contemporary urban governance.

\section{Searching for the 'Actually Existing Smart Citizen'}

In order to trace the two primary means by which we are able to identify the 'actually existing smart citizen', we turn to the case of Atlanta, Georgia and our experiences observing and, at times, participating in the development and discussion of smart city initiatives there. Atlanta represents, in many ways, precisely the kind of 'actually existing smart city' that Shelton et al (2015) attempt to call attention to. Long known as the capital of the New South and "the city too busy to hate" - an ostensible bastion of relative progressivism in a conservative region - Atlanta remains one of the country's most segregated and unequal cities (Berman 2015; Pooley 2015; Silver 2015). Pervasive racism has continued to shape the city's development, most notably through processes of 'white flight' and mass suburbanization (Kruse 2005), which have limited possibilities for regional collaboration on crucial issues, such as the expansion of public transportation into suburban counties (Henderson 2006; Basmajian 2010; Monroe 2012). This pattern of development points towards the fact that Atlanta and its broader metropolitan area have a long way to go to become 'smart', though the city isn't necessarily unique in this respect.

At the same time, however, under Mayor Kasim Reed, the city has joined the growing trend of cities attempting to position themselves as 'smart', most often as a means of promoting economic development through inter-urban competition (cf. Wiig 2016). In recent years, Atlanta has participated in a variety of smart city networks and technical assistance programs, from being host to one of the initial Innovation Delivery Teams from Bloomberg Philanthropies in 2011, to the IBM Smarter Cities Challenge in 2012, the Code for America fellowship program and City Energy Project beginning in 2014, as well as the White House's MetroLab Network in 2015 and, most recently, the Rockefeller Foundation's 100 Resilient Cities program in 2016. Though the city was unsuccessful in its bid for $\$ 50$ million as part of the US Department of Transportation's Smart Cities Challenge competition in 2016, Atlanta is one of just three cities (along with Chicago and Dallas) to be tapped as partners in AT\&T's nascent Smart Cities Framework partnership (AT\&T 2016). This wide- 
ranging participation in these various kinds of smart cities initiatives puts Atlanta among the nation's leaders in this kind of activity, further underscoring its centrality within these discussions nationwide.

Together, these initiatives provide the setting in which our observations have taken place. In particular, our empirical work draws on attendance and participation at workshops and roundtables about smart cities, some with a deliberate emphasis on developing policy ideas that can be implemented by the city government, others with a more abstract goal of increasing awareness about these initiatives among different groups spread throughout the city. This section uses these observations as a way of addressing the continued gap in empirical evidence with regards to how citizens are integrated into smart city planning and implementation exercises, both discursively and materially. Ultimately, this section of the paper attempts to push forward the critical examination of the smart citizen initiated by the likes of Gabrys (2014), Vanolo (2016), Taylor et al (2016), Joss et al (2017) and Cardullo and Kitchin (Forthcoming) by elucidating two ideal types for how citizens are (or aren't) being integrated into the making of the smart city: the general and absent citizen. While the disparate settings for our observations make it clear that "there is no one 'smart city' even within a city" (Goh 2015: 183, emphasis in the original), our research points to these trends as being generally characteristic of smart city planning in Atlanta, and likely applicable to other urban contexts as well, even if in a somewhat modified form. For like the actually existing smart city, the actually existing smart citizen is no single thing, nor does it stand in total opposition to the more conventional, celebratory narratives about smart citizenship. It is instead multifaceted and contradictory, and might be interpreted in any number of ways. Although we distinguish between these two ideal types and instances where they are seen, and indeed differentiate our empirical findings from the more conceptual contributions of Vanolo (2016) and de Waal and Dignum (2017), it is important to note that they are anything but separate and discrete, but are instead overlapping and mutually constitutive. Indeed, as we attempt to show, the generic way in which citizens tend to be treated discursively is intimately connected to, and supportive of, their discursive and material absence.

\section{A. The General Citizen: Discursive Deployments of Citizenship in the Smart City}

In February 2016, the City of Atlanta convened a two-day workshop meant to envision the future of Atlanta's smart city efforts. Held on the Georgia Institute of Technology's campus in Technology Square, a borderland between Georgia Tech and Atlanta's Midtown neighborhood that is meant to connect the technology-centric research of the university to the broader business community in the city, the workshop took place in a space emblematic of the many institutional stakeholders interested in Atlanta's smart city policies: from university researchers to industry partners and neighborhood development interests.

The workshop was organized by the City of Atlanta's Office of Innovation Delivery and Performance (or i-team), "a special projects team that drives progress on the Mayor's top-priority challenges" that "was initially formed through a grant from Bloomberg Philanthropies" (City of Atlanta n.d.). As part of the first round of such funding from Bloomberg Philanthropies, Atlanta's iteam was amongst the first five such teams across the United States. ${ }^{1}$ Though organized by the

\footnotetext{
${ }^{1}$ Since its initial investment in the cities of Atlanta, Chicago, Louisville, Memphis and New Orleans, Bloomberg Philanthropies has invested in the creation of an additional 12 i-teams across the United States, as well as two in Israel (Bloomberg Philanthropies 2014).
} 
Atlanta i-team, the workshop was largely run by a team of three consultants from Barcelona - widely recognized as one of the world's 'smartest cities' (European Innovation Partnership on Smart Cities and Communities 2015) - who were there to impart their place-based expertise onto Atlanta.

The workshop opened with three instances that demonstrate the variety of different ways that citizens and ideas of citizenship were deployed discursively at the workshop. During his welcome message, the first speaker from the Atlanta i-team explained that "we should all come to this as Atlantans". For municipal employees in different departments, the sentiment stressed how "our silos" - the variety of official, disciplinary, and even geographic affiliations of the participants might impede the discussion. The first speaker concluded by thanking the participants "for being here to shape our future". Who "our" referred to - Atlanta's residents as a whole or only those individuals in the room - is unclear. But given that several workshop participants were visiting from outside the city, the comment invoked a type of temporary citizenship that made the ostensibly place-based concerns of the City of Atlanta their concerns as well. That is, the visioning workshop represented a moment where formal and substantive citizenship are further decoupled, with individuals being endowed with the benefits of substantive citizenship while lacking formal citizenship and vice versa (cf. Holston and Appadurai 1996; Ong 2006). Newman and Safransky (2014) have described similar contexts where, under emerging conditions of austerity governance, people who are neither public officials, nor even necessarily connected to the particular place, are increasingly endowed with the authority to guide official decision-making processes. In both cases, the sentiment aligns with Hajer's (2003) claims that politics, policy, and governance are increasingly subject to new dispersed geographies, which suggests that the actually existing smart citizen isn't necessarily bound to a particular territory or place.

During an overview of the schedule and goals of the workshop, the second speaker explained that "everything we're doing is for our citizens". Here the citizen was invoked under the auspices of stewardship: those in the room were endowed with the responsibility of overseeing the well-being of Atlanta's citizens above all else. Motivated by such a responsibility to the citizens of Atlanta, the second speaker continued that the various challenges facing the city should be understood as "opportunities" rather than problems. In the third and final instance, one of the consultants from Barcelona remarked that "ultimately this is about what's best for the citizens of Atlanta". Here, the figure of the citizen comes to the fore through a type of civic paternalism, where "what's best" for Atlantans is decided on their behalf by those in the room, even if these individuals were not from the city or were unfamiliar with the various problems and struggles taking place within the city.

The ways these introductions positioned the citizen were not the only such instances during the workshop. When participants were asked to use post-it notes to brainstorm ideas for what the ideal smart city should look like, phrases like "true citizen engagement" were common, albeit with no further explanation or clarification on what that might mean. A particularly illustrative example came from a workshop attendee from the private sector. He remarked that citizens should be responsible for identifying their needs, explaining that "if it upsets you, it probably upsets a hundred thousand people, and that is a really nice little business". All of that is to say that the figure of the citizen, if not the 'smart citizen' in particular, loomed large in the way workshop organizers, facilitators and participants framed their ideas and motivations. But even as the citizen continued to be figured as central to the making of the smart city, the citizen was figured variously as both an active party and a passive recipient, as both entrepreneur and consumer, an obligation and a business opportunity. 
And yet, despite all the attention to the citizen, at times during the workshop, it wasn't clear who the citizens being discussed actually were. On the second day of the workshop, participants were divided into small groups to create proposals for new smart city policies and services. To give structure to the proposals, participants used one-page worksheets with various boxes such as "Idea Name" (title of the proposal), "Associated Challenge" (what challenge this proposal responded to), and "Partners and Roles Involved" (what institutional partnerships would be necessary for the idea's implementation). One box was titled "Benefits for city/citizens". As an example, one of the consultants from Barcelona showed a finished worksheet for a mobile application for tourists. This box contained two benefits: (1) "Inform about fancy places to visit and how to get there" and (2) "Increase economic activity around the city by attracting more tourists". It is worth noting that given the equivalence of city and citizens, this example focuses on tourists - that is, non-citizens or non-residents - and their economic impact on the city, without explicating how citizens might benefit directly from the application or indirectly from the presence of well-informed tourists.

Once the activity was in full-swing, one of us worked on a small team discussing a proposal for citywide data portal. When asking the group a seemingly simple question - "what do we mean by data here?" - the immediate response from one group member was "all of the data", while another responded simply with "big data". The subsequent exchange revealed that it was not that people in the group were unable to be specific - eventually deciding that the data portal could focus on public data otherwise accessible through FOIA requests or third-party data providers - but instead that group members were unwilling to preclude any particular type of data in the event that someone might find it useful and meaningful. As a result, the box on the worksheet titled "Target to whom it is addressed" was filled out with just the word "citizens". But the group discussion surrounding this project was more illustrative. One city employee was adamant about monetizing the data portal, an imperative he attributed to the mayor. Giving the example of businesses requesting monthly building permit reports, as well as citizens requesting information on a one-off basis, the use of "citizens" as the target served as a placeholder by demonstrating the city's accountability to the public. While ostensibly laudable, this left the true purpose of the proposal - generating monthly revenue from real estate developers, contractors or other business people - hidden under a veneer of citizen participation.

These two proposed interventions highlight an important lacuna within the workshop, and the city's smart city policymaking more generally. That is, the question of which citizens in particular went both unasked and unanswered. The titling of one box as "Benefits for city/citizens" conflates the geographic context of the city with the fractured interests of the municipal government and the variety of differently-positioned citizens within its borders. When applied to the sample proposal of a tourist-oriented smartphone application, this conflation insinuates a kind of trickle-down effect, where what is good for the city (as a center of economic activity) is automatically good for the city's citizens. Even were this causal relationship assumed to be true, the reality is that all citizens don't benefit equally from the tourist economy, and even those directly engaged in this economic sector are subject to considerable power differentials. A similar logic is at play in the example of the proposed data portal. In the group's unwillingness to be specific due to a fear of excluding someone, they failed to consider the impact that already-existing forms of social exclusion might have on different citizens' abilities to access and use such an application. They failed to consider that not all citizens might be equally predisposed to, or even technically capable of, using a web portal to access public records, or how traditional, analog FOIA requests might be handled relative to the maintenance of the portal. Indeed, the relationship between potential users of such a data portal and the broadest conception of 'citizens' in the city of Atlanta went unexplored. Even more, although 
the team implicitly saw businesses as the prototypical users of the data portal, they never addressed the potential that a data portal focused on generating revenue from local businesses might exclude many citizens from making use of it. So even in trying not to exclude anyone a priori, the proposal ultimately embedded problematic assumptions about equity, access, and resource allocation that are characteristic of most conversations about smart cities and smart citizens.

Together, these examples illustrate the prominence of what we call 'the general citizen' within discussions of smart cities. At best, the general citizen is vague and poorly defined, lacking the kind of specificity that would demonstrate a meaningful attention to issues of inequality and difference that are, or at least ought to be, at the core of discussions around urban governance. At worst, we observed the general citizen being used a vessel for stereotypes and groundless assumptions that reinscribe existing power relations and hierarchies under the auspices of paying attention to the people who make up a city. Rather than being a foil to more conventional, top-down smart city ideas, the figure of the general citizen actually serves as a means by which the status quo can largely be perpetuated, allowing decision-makers to feel as though they've adequately attended to the concerns of citizens simply because they've not deliberately or explicitly excluded anyone. That is, the discursive centrality of 'the citizen' to some otherwise-conventional smart city efforts provides a kind of justification or insulation from criticism while making little substantive difference in the design or implementation of the policy itself. Indeed, the rhetorical deployment of the general citizen is powerful precisely insofar as it is accompanied by the absence of actual citizens who might call into question the kinds of unproblematized assumptions and generally paternalistic approach discussed above.

\section{B. The Absent Citizen: (Non-)Participation in the Making of the Smart City}

While the ways that on-the-ground actors are deploying the discourse of the smart citizen, even in a generic way, when justifying their work is undoubtedly an important aspect of the story, it is important to pair the figure of the general citizen with that of 'the absent citizen'. For all of the discussion of citizens within some circles, the citizen continues to remain marginal to the actually existing smart city. While this absence is certainly evident at the discursive level, it takes on an even greater significance when paired with the reality of how actual citizens are largely absent from important discussions and decision-making efforts, which are left to be shaped by experts of one kind or another.

At a roundtable lunch discussion hosted by a local entrepreneurial organization in the summer of 2016, representatives from the municipal government, private sector and civil society organizations were present to discuss how they're engaging with the idea of smart cities and the future of government. Two moments from this event highlight the continued absence of citizens from some smart city discourses, even as they're being prominently invoked elsewhere. First, a representative from the Code for Atlanta group, ostensibly representing the most citizen-centric perspective of any of the panelists, was tasked with opening the roundtable by providing an overview of the civic hacking movement. In listing the potential beneficiaries of or constituencies for Code for Atlanta's work, government employees, researchers, journalists, entrepreneurs and innovators were included. Of course, notably absent from this list are citizens.

Later on at this same meeting, the entrepreneur on the panel, himself the head of a smart transportation company, posed a question to himself: "what's the core of a smart city?" He proceeded to mention the examples of an ambulance trying to get where it's going, or bureaucrats in 
city hall trying to figure out how to time the traffic lights. While one could reasonably interpret these examples as important - if somewhat mundane - things that could help to make everyday routines easier for people in the city, they're also indicative of the extent to which citizens aren't actually mentioned as being a substantive element of the smart city. That is, the things mentioned as being at the core of the smart city highlight the extent to which the smart city is and remains, precisely as Dan Hill mentions in his original invocation of the smart citizen, primarily about the efficiency of urban infrastructural systems, not the people living in these cities. Indeed, the initial act of inquiring about the fundamental nature of the smart city in this way further illustrates what Kitchin et al (2015) see as the major tendency for data-driven governance initiatives to search for ways of understanding cities and their functions in a reductive manner that might be able to be tracked longitudinally, despite being considered outside of their particular historical and geographical contexts. By focusing on the optimization of the surface transportation network, a largely technical exercise aided by new kinds of data-collection and automated analysis, this vision pushes to the side questions of who actually uses this infrastructure (e.g., primarily car owners) and how the current state of this system has been shaped by intensely political decisions made in the past (e.g., to privilege automobile transportation over other ways of moving around the city), naturalizing these historical and contemporary exclusions.

The exclusion of citizens from the proverbial table is perpetuated not only through discourse, but also through material practices involved in the construction of the actually existing smart city. While this paper has thus far documented instances where citizens were both discursively centered and absent, arguably the most notable part of our experience in observing smart city events has been the distinct absence of people participating in these workshops, meetings, and discussions in their capacity as citizens, rather than through some other institutional or organizational capacity. This dynamic was particularly notable at the smart cities visioning workshop discussed in the previous section. While nearly all of the attendees were indeed citizens (or, at the very least, residents) of Atlanta, all came to the workshop by special invitation, due to the expertise and organizational affiliation they brought to the table. They were representatives from some, though not all, municipal departments, such as the Atlanta Police Department and the city's Office of Sustainability, the city's two public universities and various business and non-governmental organizations. That is, though citizens were indeed involved, they were invited as experts. In this way, Atlanta's smart city planning efforts instantiate a kind of 'business class citizenship' (Sparke 2006) or what Varsanyi (2006, paraphrasing Isin 1997) describes as "the new professional class-as-transnational citizen", wherein citizenship - at least in the substantive sense - is not conferred through either inhabitance in a given territory or through ownership of landed property, but rather through ownership of cultural capital or expertise. A similar dynamic has been identified by Taylor et al (2016) in Amsterdam, where in spite of the discourse around citizen participation in smart city efforts, they were unable to identify citizens not already engaged in this work professionally who were even aware of these efforts or how they might be able to get involved in them, a trend that was particularly evident within a variety of marginalized groups. Unsurprisingly, drawing from such a group of citizens-qua-experts, as in both Atlanta and in Amsterdam, does not yield a representative sample of the city's population, either demographically or spatially, and thus works to further engrain particular kinds of bias into the planning and policymaking process from the start.

Even more, none of the participants in this workshop, nor in the other workshops and meetings we observed, were even elected representatives, but were instead municipal bureaucrats or informal representatives of certain organization (e.g. the Code for Atlanta representative discussed above). One workshop participant told us at the end of the first day that they had hoped for more 
participation among different kinds of people, as "the cutting edge" of smart cities is all about "social inclusion". But this individual also said that as much as they hoped students or people of color, among others, would be present for such a meeting, they also hoped for more participation from the private sector. So while it is perhaps a positive sign that some participants were able to recognize some of the constituencies missing from the room, such a response also highlights the challenges to making everyday citizens the center of any smart city effort.

A similar absence was noted in the Startup Atlanta event. In its most basic set-up, the panel was composed of four men, all of whom again had a particular expertise and organizational affiliation that led to their inclusion. During the Q\&A session at the end of the panel, a woman of color in the audience remarked that "these types of events always seem to draw the same group of people". While it is somewhat ambiguous what exactly she meant by 'same', the implication is that conversations about these topics tend to be dominated by white men, whether they be invited panelists or simply members of the audience, who are already well-connected in the city and its technology sector. Her comment alludes to a categorical and systemic homogeneity, the recognition and vocalization of which is particularly stark in contrast to the comments made by panelists at this event, which demonstrated a lack of faculty in discussing issues of citizenship, inequality and difference within the context of the smart city.

Indeed, just as important as the line of questioning about how this lack of representativeness might be rectified were the responses from the panelists. The representative from the City of Atlanta's iteam noted that in order to include these more marginalized groups, the city was partnering with organizations in Atlanta's historic Westside, a conglomeration of largely poor and African-American neighborhoods just to the west of downtown. Specifically, he mentioned the Westside Future Fund, a local business elite-led organization that's attempting to ameliorate some of the negative impacts associated with the construction of the new Mercedes Benz Stadium and associated redevelopment activities at the Westside's periphery, though certainly not the group that one would call the most representative of longtime residents who have historically been marginalized within the city's planning process. On the other hand, the aforementioned smart transportation executive turned the question about a lack of citizen participation into a question of a lack of venture capital funding. His assumption was, in effect, that the city's technology community could only be inclusive when there was more money to go around. Together, these examples further demonstrate the pervasive neoliberal understanding of citizenship that is mobilized through these instantiations of the 'actually existing smart citizen'. The failure to not only actively include, but even consider, marginalized people simultaneously places the onus on these citizens to be active on their own accord, but also to not be a burden on society in such a way that their needs be actively considered (cf. Ong 2003). Through this vision, it is the deviation from the norms of what is considered to be normal or acceptable that works to justify the exclusion of these citizens from such discussions about policy and planning.

But citizens aren't entirely absent from this 'actually existing smart city'. Initiatives like the Westside Communities Alliance's Data Dashboard ${ }^{2}$ show that citizens and community organizations are actively enmeshing themselves in some of the overarching discourses and practices of smart cities and data-driven governance. With the goal of "allow[ing the] community to use data vibrantly, well and in its own interest", the Data Dashboard is explicitly positioned as tool for the Westside community to use in its fight against gentrification and encroachment by the Mercedes Benz

${ }^{2}$ http://wcadatadashboard.iac.gatech.edu/Home/ 
Stadium project (O’Connell 2017). By integrating not just quantitative data, but also qualitative and archival data, but also centering this data at the geographic scale of Atlanta's neighborhood planning units in order to be more legible to residents and relevant to policy discussions, the Data Dashboard represents a means by which citizens can tell their own stories, demonstrating the interconnectedness of different issues that they confront on an everyday basis, such as the relationship between housing affordability, jobs and transit accessibility. But even as Westside residents, precisely the kind of citizens that tend to be absent from official city visioning workshops or tech community roundtables, are constructing their alternative vision of what the (smart) city might look like, they also remain largely separate from the broader discourse of the smart city, and the institutions that are responsible for creating it. As one WCA staffer noted at the public launch of the Data Dashboard at Georgia Tech last winter, the Data Dashboard project has largely been ignored by the city and by major funders who might be able to provide resources that would help to extend its technical capabilities and allow for more outreach activity around its use. Implicit in this comment was its direction at some of the very same business-led and elite institutions mentioned above by city officials as the lone examples of how the city is attempting to engage with marginalized populations. So, while there is on the one hand a clear presence of something approximating 'actually existing smart citizens' - people using and engaging with data in order to make alternative representations of, and claims on, their neighborhoods and the city as a whole these citizens and their efforts remain largely ignored and outside of the formal institutions responsible for creating the smart city. This is perhaps due in part to their oppositional nature, or the fact that at the same time as they adopt some of the rhetoric and practices of 'smartness', they also politicize these discourses, disrupting one of the fundamental tenets of the smart city as it is commonly operationalized.

\section{Conclusion}

Ultimately, all of this points towards the idea that, in practice, the 'actually existing smart citizen' might not really exist at all. At the very least, the emerging discourse around smart citizenship is clearly not matched by the realities of how citizens are discussed and enrolled in the process of making the smart city in Atlanta. That is, far from being a foil that disrupts the conventional understanding and operation of smart cities initiatives, the actually existing smart citizen has a much more ambivalent position in relation to the hegemonic conception of the smart city. Even where 'smart citizens' actually do exist, they don't seem to be recognized as such, and remain largely on the periphery of these structures of power and decision-making processes, revealing the limits to the smart city and its ability to reckon with disparate voices and political claims.

But focusing on the alternate presence or absence of citizens in these settings belies the more general problem of the 'smart citizen' discourse. While failing to include the voices of 'average' citizens in decision-making processes, or ignoring those who attempt to participate, is an important failing, it's important to note how the smart citizen represents and enables a broader reconfiguration of citizenship, and of urban governance, more generally. Rather than being a kind of place-based, formal legal status that's more-or-less universally applied, we ought to understand 'smart citizenship' as a form of substantive citizenship that's constantly being performed through the invocation of particular forms of expertise and participation in policy-making exercises, to the exclusion of those who in fact hold formal citizenship rights within a given polity. Through such a reconfiguration of citizenship around expertise, powerful actors are able to build 'from the bottom up' almost precisely the same vision of the city inherited from the more stereotypical, top-down, neoliberal approach to 
the smart city, albeit now simply constructed piecemeal and with some degree of consent or 'buy-in' from the appropriate constituencies of experts-qua-citizens.

While it may logically follow from our analysis that any smart city efforts ought simply to be more deliberate about attempts to include citizens in planning and decision-making efforts, we also caution against such a simplistic understanding of potential solutions. For, as Fainstein (2000) has argued, "[c]ity building for the benefit of nonelite groups requires empowering those who are excluded not just from discussions but from structural positions that allow them genuine influence" (461). As much as inviting new and more diverse kinds of people or deploying technologies sensitive to local needs are important, equally as important is recognizing that the smart citizen does not exist outside of the discourse of the smart city, nor outside the material constraints of the neoliberal city more generally. As Mark Shepherd and Antonina Simeti argue, "[i]n the end, both the Smart City and the Smart Citizen result in the same rhetorical paralysis" (Shepherd and Simeti 2014: 17). Like the smart city discourse in general, the mobilization of the smart citizen discourse assumes that all problems are simply technocratic problems of execution or implementation: we simply need 'the right technology', 'the right information' or 'the right people' to make things work. If something isn't working, simply change the technology and/or the people.

That is, even though the smart citizen represents a scalar shift within discussions of technological solutions to urban problems, this way of approaching the challenge represented by smart cities is still situated within the same overarching discourse: both the smart city and smart citizen always already exist within a much broader set of assumptions related to the centrality of cities in the global economy, citizenship as a trans-local, transactional, or performative process, information technology as fundamentally 'disruptive', and the necessity of both the private market and responsibilized volunteer citizens to the provision of public services. Both the discourse and practice of smart citizenship exists within the same power geometry that produces the smart city more generally, with their seeming opposition to one another belying both their common grounding in market- and technology-centric ways of approaching contemporary urban problems, as well as their divorce from the actual practices of democratic citizenship and city-making. 


\section{$\underline{\text { V. References }}$}

Allessie, David. 2016. "Only Smart Citizens can enable true Smart Cities." CitizenLab. 12 April. Available from: http://citizenlab.co/blog/citizensourcing-en/smart-citizens-can-enabletrue-smart-cities /

Arnstein, Sherry R. 1969. "A Ladder of Citizen Participation." Journal of the American Institute of Planners 35 (4): 216-24.

AT\&T. 2016. "AT\&T Launches Smart Cities Framework with New Strategic Alliances, Spotlight Cities, and Integrated Vertical Solutions”. Press Release. 5 January. Available from: http://about.att.com/story/launches smart cities framework.html

Barns, Sarah. 2016. "Mine Your Data: Open Data, Digital Strategies and Entrepreneurial Governance by Code." Urban Geograpby 37 (4): 554-71.

Basmajian, Carlton. 2010. "Projecting Sprawl? The Atlanta Regional Commission and the 1975 Regional Development Plan of Metropolitan Atlanta.” Journal of Planning History 9 (2): 95121.

Berman, Mark. 2015. “Atlanta is the country's most unequal city again.” The Washington Post. 17 March. Available from: https://www.washingtonpost.com/news/postnation/wp/2015/03/17/altanta-is-the-countrys-most-unequal-city-again/

Bloomberg Philanthropies. 2014. "Bloomberg Philanthropies Expands Innovation Teams Program to 12 New American Cities.” Press Release. 15 December. Available from: https://www.bloomberg.org/press/releases/bloomberg-philanthropies-expands-innovationteam-program-12-new-american-cities /

Cardullo, Paolo, and Rob Kitchin. Forthcoming. "Being a 'Citizen' in the Smart City: Up and down the Scaffold of Smart Citizen Participation in Dublin, Ireland." GeoJournal.

City of Atlanta. n.d. "Office of Innovation Delivery and Performance." Available from: http://www.atlantaga.gov/index.aspx?page $=133$

Cowley, Robert, Simon Joss, and Youri Dayot. Forthcoming. "The Smart City and Its Publics: Insights from across Six UK Cities." Urban Research and Practice.

Datta, Ayona. 2015. “New Urban Utopias of Postcolonial India: 'Entrepreneurial Urbanization' in Dholera Smart City, Gujarat.” Dialogues in Human Geography 5 (1): 3-22.

de Waal, Martijn, and Marloes Dignum. 2017. "The Citizen in the Smart City. How the Smart City Could Transform Citizenship.” it - Information Technology 59 (6): 263-273.

Ehn, Pelle, Elisabet M. Nilsson, and Richard Topgaard. 2014. Making Futures: Marginal Notes on Innovation, Design, and Democracy. MIT Press.

European Innovation Partnership on Smart Cities and Communities. 2015. "Barcelona is the World's Smartest City 2015.” Press Release. Available from: https://eusmartcities.eu/content/barcelona-world $\% \mathrm{E} 2 \% 80 \% 99$ s-smartest-city-2015

Eymeri, Julien. 2014. "Eerie Video Shows Masdar City—The Sustainable City Of The Future-Has No One In It". FastCo.Exist. 23 September. Available from:

http://www.fastcoexist.com/3035446/eerie-video-shows-masdar-city-the-sustainable-cityof-the-future-has-no-one-in-it 
Fainstein, Susan S. 2000. "New Directions in Planning Theory." Urban Affairs Review 35 (4): 451-78.

Gabrys, Jennifer. 2014. "Programming Environments: Environmentality and Citizen Sensing in the Smart City." Environment and Planning D: Society and Space 32 (1): 30-48.

Goh, Kian. 2015. “Who's Smart? Whose City? The Sociopolitics of Urban Intelligence.” In Planning Support Systems and Smart Cities, eds. S. Geertman, J. Ferreira Jr, R. Goodspeed, and J. Stillwell. Springer. pp. 169-187.

Gordon, Eric, and Edith Manosevitch. 2011. “Augmented Deliberation: Merging Physical and Virtual Interaction to Engage Communities in Urban Planning." New Media \& Society 13 (1): 75-95.

Greenfield, Adam. 2013. Against the Smart City. Do Projects.

Hajer, Maarten. 2003. "Policy without Polity? Policy Analysis and the Institutional Void." Policy Sciences 36 (2): 175-95.

Halpern, Orit, Jesse LeCavalier, Nerea Calvillo, and Wolfgang Pietsch. 2013. "Test-Bed Urbanism." Public Culture 25 (2): 272-306.

Henderson, Jason. 2006. "Secessionist Automobility: Racism, Anti-Urbanism, and the Politics of Automobility in Atlanta, Georgia." International Journal of Urban and Regional Research 30 (2): 293-307.

Hill, Dan. 2013. “On the Smart City; Or, a 'Manifesto' for Smart Citizens Instead.” Cityofsound. 1 February. Available from: http://www.cityofsound.com/blog/2013/02/on-the-smart-city-acall-for-smart-citizens-instead.html

Hollands, Robert G. 2008. “Will the Real Smart City Please Stand up? Intelligent, Progressive or Entrepreneurial?” City 12 (3): 303-20.

Hollands, Robert G. 2015. "Critical Interventions into the Corporate Smart City." Cambridge Journal of Regions, Economy and Society 8 (1): 61-77.

Holston, James, and Arjun Appadurai. 1996. "Cities and Citizenship.” Public Culture 8 (2): 187-204.

Hoyng, Rolien. 2016. "From Infrastructural Breakdown to Data Vandalism: Repoliticizing the Smart City?” Television \& New Media 17 (5): 397-415.

Isin, Engin F. 1997. "Who Is the New Citizen? Towards a Genealogy.” Citizenship Studies 1 (1): 11532.

Joss, Simon, Matthew Cook, and Youri Dayot. 2017. "Smart Cities: Towards a New Citizenship Regime? A Discourse Analysis of the British Smart City Standard." Journal of Urban Technology 24 (4): 29-49.

Kelty, Christopher M. (2017) "Too Much Democracy in All the Wrong Places: Toward a Grammar of Participation." Current Anthropology 58 (15): S77-S90.

Kitchin, Rob. 2014. “The Real-Time City? Big Data and Smart Urbanism.” GeoJournal 79 (1): 1-14.

Kitchin, Rob. 2015. "Making Sense of Smart Cities: Addressing Present Shortcomings." Cambridge Journal of Regions, Economy and Society 8 (1): 131-36.

Kitchin, Rob, Tracey P. Lauriault, and Gavin McArdle. 2015. "Knowing and Governing Cities through Urban Indicators, City Benchmarking and Real-Time Dashboards." Regional Studies, Regional Science 2 (1): 6-28. 
Kruse, Kevin M. 2005. White Flight: Atlanta and the Making of Modern Conservatism. Princeton University Press.

Le Dantec, Christopher A., Caroline Appleton, Mariam Asad, Robert Rosenberger, and Kari Watkins. 2016. "Advocating through Data: Community Visibilities in Crowdsourced Cycling Data." In Bicycle Justice and Urban Transformation: Biking for All?, eds. A. Golub, M.L. Hoffmann, A.E. Lugo, and G.F. Sandoval. Routledge. pp. 70-85.

Lodato, Thomas James, and Carl DiSalvo. 2016. "Issue-Oriented Hackathons as Material Participation.” New Media \& Society 18 (4): 539-57.

Mattern, Shannon. 2014. “Interfacing Urban Intelligence.” Places Journal. Available from: https://placesjournal.org/article/interfacing-urban-intelligence/

Mattern, Shannon. 2016. "Instrumental City: The View from Hudson Yards, circa 2019." Places Journal. Available from: https://placesjournal.org/article/instrumental-city-new-yorkhudson-yards/

McNeill, Donald. 2015. "Global Firms and Smart Technologies: IBM and the Reduction of Cities." Transactions of the Institute of British Geographers 40 (4): 562-74.

Monks, Keiron. 2015. "CITE: The $\$ 1$ billion city that nobody calls home”. CNN.com. 6 October. Available from: http://www.cnn.com/2015/10/06/business/test-city/

Monroe, Doug. 2012. "Where It All Went Wrong: If Only We Could Undo the MARTA Compromise of 1971." Atlanta Magazine. 1 August. Available from: http://www.atlantamagazine.com/great-reads/marta-tsplost-transportation/

Newman, Andrew, and Sara Safransky. 2014. "Remapping the Motor City and the Politics of Austerity.” Anthropology Now 6 (3): 17-28.

O’Connell, Katie. 2017. “The Difference Data Makes: Combatting Inequality with the Westside Communities Alliance Data Dashboard". Atlanta Studies. Available from: https://scholarblogs.emory.edu/atlantastudies/2017/03/30/the-difference-data-makescombatting-inequality-with-the-westside-communities-alliance-data-dashboard/

Offenhuber, Dietmar. 2015. "Infrastructure Legibility—a Comparative Analysis of Open311-Based Citizen Feedback Systems." Cambridge Journal of Regions, Economy and Society 8 (1): 93-112.

Ong, Aihwa. 2003. Buddha Is Hiding: Refugees, Citizenship, the New America. University of California Press.

Ong, Aihwa. 2006. "Mutations in Citizenship.” Theory, Culture \& Society 23 (2-3): 499-505.

Perng, Sung-Yueh, and Rob Kitchin. 2018. "Solutions and Frictions in Civic Hacking: Collaboratively Designing and Building Wait Time Predictions for an Immigration Office." Social \& Cultural Geography 19 (1): 1-20.

Pooley, Karen. 2015. “Segregation's New Geography: The Atlanta Metro Region, Race, and the Declining Prospects for Upward Mobility." Southern Spaces. Available from: https://southernspaces.org/2015/segregations-new-geography-atlanta-metro-region-raceand-declining-prospects-upward-mobility

Power, Donal. 2016. “Are smart citizens getting lost in the rush to build smart cities?” ReadWrite. 11 April. Available from: http://readwrite.com/2016/04/11/smart-citizens-lost-rush-makesmart-cities-cl4/ 
President's Council of Advisors on Science and Technology. 2016. Technology and the Future of Cities.

Report to the President. Available from:

https://www.whitehouse.gov/sites/default/files/microsites/ostp/PCAST/pcast cities rep ort final 3 2016.pdf

Ratti, Carlo. 2016. "While governments talk about smart cities, it's citizens who create them." The Conversation. 2 June. Available from: https://theconversation.com/while-governments-talkabout-smart-cities-its-citizens-who-create-them-59230

Sadowski, Jathan, and Frank Pasquale. 2015. "The Spectrum of Control: A Social Theory of the Smart City." First Monday 20 (7).

Sassen, Saskia. 2012. "Urbanising technology". The Electric City Newspaper. Urban Age Electric City Conference, LSE Cities . Available from: https://lsecities.net/media/objects/articles/urbanising-technology/en-gb/

Secor, Anna J. 2003. "Citizenship in the City: Identity, Community, and Rights Among Women Migrants to Istanbul.” Urban Geography 24 (2): 147-68.

Shein, Esther. 2016. "Without smart citizens, smart cities don't really stand a chance." FierceCities. 21 April. Available from:

http://web.archive.org/web/20160423235240/http://www.fiercecities.com/story/withoutsmart-citizens-smart-cities-dont-really-stand-chance/2016-04-21

Shelton, Taylor, Matthew Zook, and Alan Wiig. 2015. “The 'Actually Existing Smart City.”' Cambridge Journal of Regions, Economy and Society 8 (1): 13-25.

Shepherd, Mark and Antonina Simeti. 2014. “What's so Smart about the Smart Citizen?”. In Smart Citizens, eds. D. Hemment and A. Townsend. FutureEverything. pp. 13-18.

Silver, Nate. 2015. “The Most Diverse Places Are Often The Most Segregated.” FiveThirtyEight. 1 May. Available from: https://fivethirtyeight.com/features/the-most-diverse-cities-are-oftenthe-most-segregated/

Söderström, Ola, Till Paasche, and Francisco Klauser. 2014. "Smart Cities as Corporate Storytelling." City 18 (3): 307-20.

Sparke, Matthew B. 2006. "A Neoliberal Nexus: Economy, Security and the Biopolitics of Citizenship on the Border." Political Geography 25 (2): 151-80.

Taylor, Linnet, Christine Richter, Shazade Jameson, and Carmen Perez de Pulgar. 2016. "Customers, Users or Citizens? Inclusion, Spatial Data and Governance in the Smart City." Maps4Society Final Project Report. University of Amsterdam. Available from: http://papers.ssrn.com/sol3/papers.cfm?abstract id=2792565

The White House. 2015. "Fact Sheet: Administration Announces New “Smart Cities” Initiative to Help Communities Tackle Local Challenges and Improve City Services”. Press Release. 14 September. Available from: https://www.whitehouse.gov/the-pressoffice/2015/09/14/fact-sheet-administration-announces-new-smart-cities-initiative-help

Tironi, Martín, and Matías Valderrama. Forthcoming. "Unpacking a Citizen Self-Tracking Device: Smartness and Idiocy in the Accumulation of Cycling Mobility Data." Environment and Planning D: Society and Space. 
Townsend, Anthony. 2013. Smart Cities: Big Data, Civic Hackers, and the Quest for a New Utopia. W. W. Norton \& Company.

Townsend, Anthony. 2014. “To Know Thy City, Know Thyself”. In Smart Citizens, eds. D. Hemment and A. Townsend. FutureEverything. pp. 23-26.

Upadhyaya, Arun. 2015. "Smart city needs smart citizens, too." The Times of India. 12 August. Available from: http://timesofindia.indiatimes.com/city/nagpur/Smart-city-needs-smartcitizens-too/articleshow/48445048.cms

Vanolo, Alberto. 2014. "Smartmentality: The Smart City as Disciplinary Strategy." Urban Studies 51 (5): 883-98.

Vanolo, Alberto. 2016. "Is There Anybody out There? The Place and Role of Citizens in Tomorrow's Smart Cities.” Futures 82: 26-36.

Varsanyi, Monica W. 2006. “Interrogating 'Urban Citizenship' Vis-à-Vis Undocumented Migration.” Citizenship Studies 10 (2): 229-49.

Viitanen, Jenni, and Richard Kingston. 2014. "Smart Cities and Green Growth: Outsourcing Democratic and Environmental Resilience to the Global Technology Sector." Environment and Planning $A 46$ (4): 803-19.

White, James Merricks. 2016. “Anticipatory Logics of the Smart City's Global Imaginary.” Urban Geography 37 (4): 572-89.

Wiig, Alan. 2015. “IBM’s Smart City as Techno-Utopian Policy Mobility.” City 19 (2-3): 258-73.

Wiig, Alan. 2016. "The Empty Rhetoric of the Smart City: From Digital Inclusion to Economic Promotion in Philadelphia." Urban Geography 37 (4): 535-53.

Wilson, Matthew W. 2011. "Data Matter(s): Legitimacy, Coding, and Qualifications-of-Life." Environment and Planning D: Society and Space 29 (5): 857-872.

Zandbergen, Dorien. 2017. "We Are Sensemakers': The (Anti-)Politics of Smart City Co-Creation." Public Culture 29 (3): 539-62. 